\title{
Synthetic cannabinoid and synthetic cathinone use in Hungary: A literature review
}

\author{
M KAPITÁNY-FÖVÉNY ${ }^{1,2 *}$ and J RÁCZ $Z^{1,3}$ \\ ${ }^{1}$ Faculty of Health Sciences, Semmelweis University, Budapest, Hungary \\ ${ }^{2}$ Drug Outpatient Centre, Nyírő Gyula National Institute of Psychiatry and Addictions, Budapest, Hungary \\ ${ }^{3}$ Faculty of Education and Psychology, Institute of Psychology, Eötvös Loránd University, Budapest, Hungary
}

(Received: September 25, 2017; revised manuscript received: November 8, 2017; accepted: January 17, 2018)

\begin{abstract}
Purpose: In the past decade, novel psychoactive substances (NPSs) gained a significant role on the contemporary drug scene. Synthetic cathinones and synthetic cannabinoids are the most common NPSs both in Hungary and worldwide. This study aims to provide a literature review on the Hungarian characteristics related to the use of these NPSs. Materials and methods: Available literature regarding synthetic cathinone and cannabinoid use in Hungary was overviewed and structured into (a) epidemiological studies, (b) studies on the subjective and somatic effects, and (c) studies on toxicity and adverse consequences. Published papers between 2007 and 2017 were identified using PubMed and MATARKA search engines. Results: One hundred twenty-six papers were identified and after exclusion, 54 papers remained for in-depth analysis. Most of the reviewed studies were providing epidemiological information regarding the NPSs of our interest. Hungarian prevalence rates were not higher than the European averages. Identified risks of these NPSs consisted of drug-induced psychosis, further severe psychiatric symptoms, and fatal overdose. Injecting of cathinones was also a commonly reported phenomenon, mostly among clients of needle-exchange programs. Conclusion: Based on the reviewed body of research, necessary information is available to plan effective prevention and intervention programs and establishes specific therapeutic guidelines for the treatment of NPS users.
\end{abstract}

Keywords: novel psychoactive substances, synthetic cathinones, synthetic cannabinoids, literature review, Hungary

\section{INTRODUCTION}

In the past decade, novel psychoactive substances (NPSs) gained a significant role on the contemporary drug scene. With a decreasing purity and availability of 3,4methylenedioxymethamphetamine (MDMA), cocaine, or heroin, NPSs such as synthetic cathinones became preferred alternates of already banned substances.

The European Monitoring Centre for Drugs and Drug Addiction currently monitors more than 450 NPSs [1], including phenethylamines, opioids, tryptamines, benzodiazepines, arylalkylamines, and piperazines, yet highest prevalence rates were found regarding the use of synthetic cathinones and synthetic cannabinoids both in the adult/ general [2] and adolescent populations [3]. The majority of the published prevalence rates regarding NPS use were derived from seizure data or studies that examined nonrepresentative samples - e.g., club-goers or the gay community; therefore, these results need to be considered as rough estimates due to the lack of standardised measures. Nevertheless, between 2008 and 2013, a sevenfold increase in the number of seized NPS was reported across Europe [1]. Among synthetic cathinones, mephedrone (4-methylmethcathinone), pentedrone [2-(methylamino)-1-phenylpentan-1-one], methylone (3,4methylenedioxy-N-methylcathinone), 4-methylethcathinone (4-MEC), and 3,4-methylenedioxypyrovalerone (MDPV) were the most frequently consumed substances, whereas JWH-type products [e.g., JWH-018: (1-pentyl-3-(1-naphthoyl)indole)] were the most popular synthetic cannabinoids in the past few years.

Growing popularity of NPSs can be explained by several factors, including their easy availability, relatively low price, or the fact that they can give a better quality higher than formerly banned psychoactive substances [4]. Easy access to these drugs is further facilitated by the globalisation of the web, thus the widespread marketing of NPSs through online platforms.

An increasing injection rate of synthetic cathinones can also be mentioned as a novel public health concern. A tendency to inject mephedrone or MDPV was reported by several countries, such as Hungary, Austria, Romania, Slovenia, and Ireland [5-9].

This study aims to provide a brief overview of Hungary's NPS-related characteristics by searching the literature of the past 10 years, as 2007 was the first year when mephedrone entered the drug scene, followed by the burst of NPS drug market.

\footnotetext{
* Corresponding author: Máté Kapitány-Fövény; Faculty of Health Sciences, Department of Addictology, Semmelweis University, Vas utca 17, Budapest H-1088, Hungary; E-mail: m.gabrilovics@gmail.com
}

This is an open-access article distributed under the terms of the Creative Commons Attribution-NonCommercial 4.0 International License, which permits unrestricted use, distribution, and reproduction in any medium for non-commercial purposes, provided the original author and source are credited, a link to the CC License is provided, and changes - if any - are indicated. 


\section{MATERIALS AND METHODS}

We overview the most relevant findings of the available literature regarding NPS use characteristics in Hungary and present these results by the following structure: (a) epidemiological studies, (b) studies on the subjective and somatic effects, and (c) studies on toxicity and adverse consequences.

Published papers between January 1, 2007 and September 18, 2017 were identified using PubMed for international publications (or papers with an English abstract) and MATARKA search engine for national publications, applying the keywords: "NPS/ÚPSZ" or "Novel Psychoactive Substance*/Új Pszichoaktív Szer*" or "cathinone*/katinon*" or "mephedrone/mefedron" or "MDPV" or "pentedrone/ pentedron*" or "methylone/metilon*" or "4-MEC" or "synthetic cannabinoid/szintetikus kanninoid*" or "JWH*" and "Hungar*". Since synthetic cathinones and cannabinoids were the most popular NPSs both in Hungary and worldwide, we focused only on these substances during our search process.

\section{RESULTS}

As a result, 100 papers were identified through PubMed and 26 papers through MATARKA. As the next step, altogether 90 papers were excluded from the analysis. Major reason of exclusion $(n$ of exclusion $=56)$ was irrelevant content [e.g., papers using the abbreviation "NPs" for "nanoparticles" $(n=37)$ or "neuropeptide S" $(n=2)$, "natural products" $(n=2)$, "nasal powders" $(n=1)$, "nail psoriasis severity" $(n=1)$, "neuropsychiatric symptoms" $(n=1)$, "new principles" $(n=1)$, "nasal polyposis" $(n=1)$ or "agricultural non-point (diffuse) sources" $(n=1)$ and not for "novel/new psychoactive substances", or the term "ÚPSZ" for "Új Pedagógiai Szemle" $(n=3)$ instead of "Új Pszichoaktív Szer", or the term "MDPV" for "Muscovy duck parvovirus" $(n=2)$ instead of "methylenedioxypyrovalerone" or "MEC" for a Hungarian media agency $(n=3)$ or the "mecA gene" $(n=1)$ instead of "methylethcathinone"]. In case of six papers, an overlap was observed between PubMed and MATARKA search results and therefore labelled as "duplicate results". Further exclusions derived from the fact that the excluded papers were providing a general overview of NPSs and their legislative system and did not present Hungarian specificities $(n=15)$, or presented the effects of NPSs using animal models $(n=5)$, or introduced state-of-the-art analytical methods for toxicology $(n=6)$. One study dealt with kratom - labelled as NPS - but not with synthetic cathinones or cannabinoids, whereas another study focused on the endogenous cannabinoid system, instead of the effects of synthetic cannabinoids.

After exclusion, 36 papers remained in the analysis for in-depth review. With regard to epidemiological data, annual reports of the Hungarian National Focal Point $(n=10)$ were additionally reviewed in the same time period (2007-2017), as these papers were not identified either through PubMed, or through MATARKA search results. Annual reports of the Hungarian National Focal Point were screened in order to identify further publications. As a result, eight additional papers were included.

Therefore, altogether 54 papers remained for review. Figure 1 presents the flowchart of the search protocol and the steps of paper exclusion/inclusion.
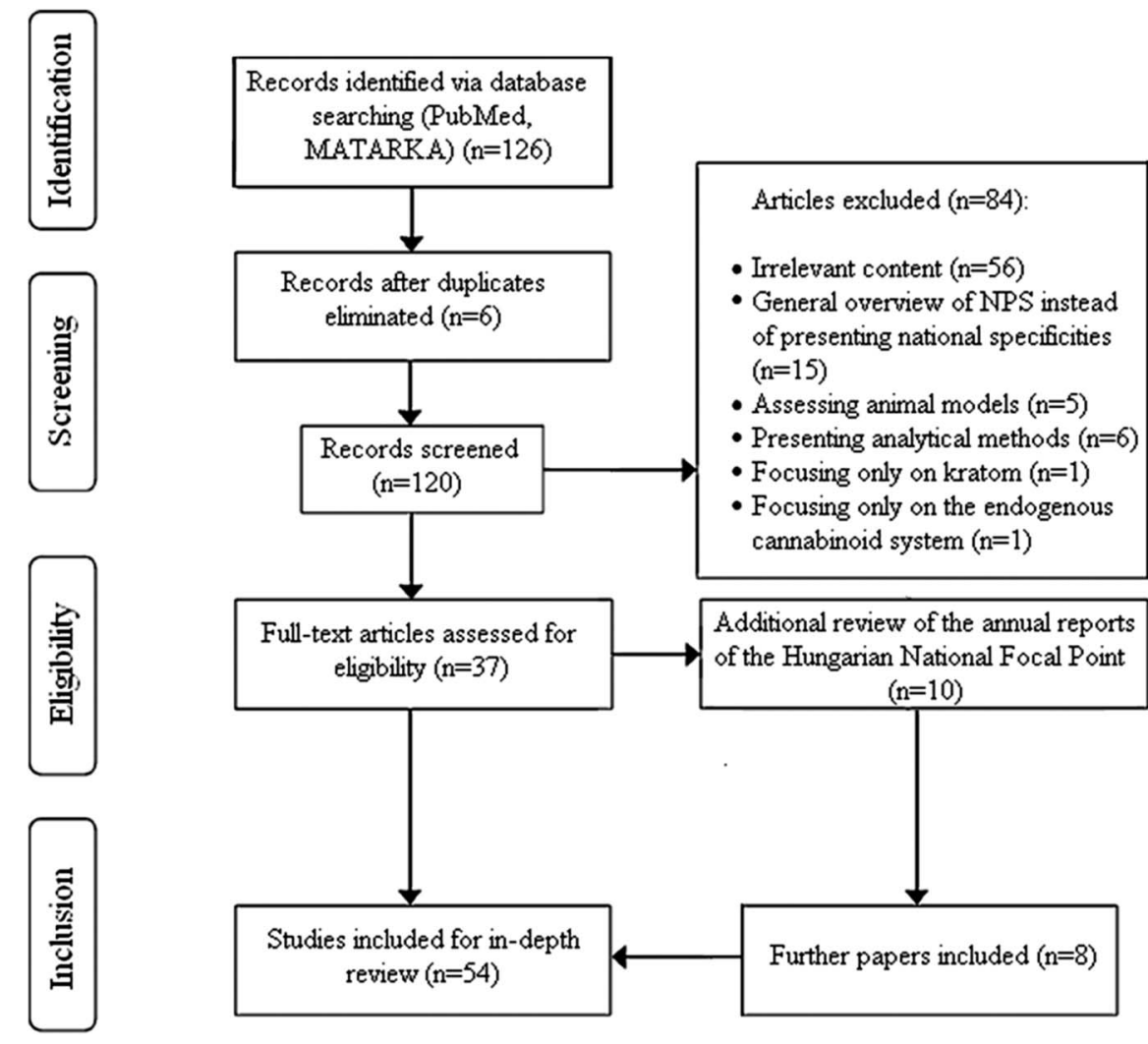

Figure 1. Flowchart of the review process 


\section{Epidemiological studies}

With regard to the epidemiological aspects of either synthetic cathinone or cannabinoid consumption, many of the reviewed studies provided estimates by analysing biological samples of substance users. Árok et al. [10] examined the urine/blood samples of 2,976 suspected drug users in South-East Hungary between 2008 and 2015. A total of 1,777 subjects provided a positive test for any psychoactive substances. Based on their results, the most frequently used synthetic cathinone was mephedrone in 2010 ( $n$ of positive tests $=13$ ), 4-MEC ( $n$ of positive tests $=31$ ), methylone ( $n$ of positive tests $=28$ ), MDPV ( $n$ of positive tests $=25)$, 4-fluoromethcathinone ( $n$ of positive tests $=12$ ), and 4-fluoroamphetamin ( $n$ of positive tests $=9$ ) in 2011, as well as pentedrone between 2012 and 2015 ( $n$ range of positive tests $=38-73$ ). Authors further added that the frequency of substances in the assessed biological samples was comparable to seizure rates as well. Members of the same research group [11] found that pentedrone was the most commonly used stimulant NPS in Budapest as well not just in the region of southeast Hungary. The increase in the number of pentedrone-related positive biological samples was associated with a change in the legislative status of mephedrone, MDPV, methylone, or 4-MEC. In line with these findings, Tóth et al. [12] identified a 7\% prevalence of mephedrone use in 2010 by assessing 5,386 samples derived from participants of Budapest and Szeged, indicating that this NPS was still popular in that year. The emergence of mephedrone consumption between 2008 and 2010 was confirmed by Ujváry [13] as well. The assessment of biological samples in order to identify synthetic cannabinoid products was not reported by these studies. Regarding the national legislative system, Ujváry $[14,15]$ described that in case of synthetic cannabinoids, head shops terminated the distribution of these products after 2008, due to the interventions of the National Public Health and Medical Officer Service (ÁNTSZ). In 2011, five JWH types were registered in the B-list, whereas in 2012, further synthetic cannabinoid products entered the C-list of legislation [15]. In case of synthetic cathinones, mephedrone was banned in January 2011, followed by the legislation of other cathinone derivatives.

Considering further epidemiological data, first mention of either synthetic cathinone or cannabinoid use occurred in the 2010 annual report of the Hungarian National Focal Point [16], although without providing exact prevalence rates. As cited by the 2011 annual report [16] as well, the Health Behaviour in School-aged Children study [17] identified a lifetime prevalence rate of synthetic cathinone use below 1\% in 2010. However, in 2011, the European School Survey Project on Alcohol and Other Drugs (ESPAD) study found a $6 \%$ lifetime prevalence rate of mephedrone use among school-aged respondents [18]. The findings of the 2014 HBSC study [19] showed a 4.5\% lifetime prevalence of NPS use (including synthetic cathinones), indicating a significant increase since 2010. According to the results of the 2015 ESPAD study [20], lifetime prevalence of synthetic cannabinoids was $10.1 \%$; therefore, this NPS reached the second place in the consumption structure of school-aged respondents. In 2015, NPS use of the general population was also examined [21]. Lifetime prevalence was $1.9 \%$ for synthetic cannabinoid use and only $0.6 \%$ for mephedrone.

The 2012 annual report of the Reitox National Focal Point [16] presented an increase in the frequency of synthetic cannabinoid seizures between $2010(5 \mathrm{~kg})$ and 2011 $(51 \mathrm{~kg})$ as well as in the case of synthetic cathinones seizures (from 2010: $353 \mathrm{~kg}$ to 2011: $595 \mathrm{~kg}$ ), based on the data provided by the Hungarian Institute for Forensic Sciences (BSZKI). The frequency of seizures regarding either synthetic cannabinoids (from 2011: $51 \mathrm{~kg}$ to 2012: $61 \mathrm{~kg}$ ) or cathinone derivatives (from 2011: $595 \mathrm{~kg}$ to $2012: 700 \mathrm{~kg}$ ) further increased between 2011 and 2012 [16]. This increasing tendency remained throughout the following years [16].

In 2011, among 66 drug-using women [either pregnant or with a child(ren) below the age of 2], $28.8 \%$ used mephedrone, $25.8 \%$ used MDPV, and 6.1\% used synthetic cannabinoids at least once in their lifetimes [22]. In 2012, among 44 drug-using women [either pregnant or with a child(ren) below the age of 2], $63.6 \%$ used MDPV, 50\% used pentedrone, $36.4 \%$ used mephedrone, and $34.1 \%$ used synthetic cannabinoids at least once in their lifetimes [22].

The prevalence rates of synthetic cathinone use were also observed among the clients of needle-exchange programs (NEPs). Csák et al. [23] gathered information from 16 Hungarian-registered NEPs regarding the substance-use characteristics of their clients. As a result, all NEPs reported mephedrone use in 2010 and among clients of 14 NEPs, intravenous mephedrone use was also observed. Csák et al. [9] described a shift to injecting MDPV in 2011, with 48.1\% of injecting drug user (IDU) clients of the Blue Point NEP intravenously administering this cathinone derivative. This shift to injecting cathinones was confirmed by the study of Péterfi et al. [24] as well. Clients of the Blue Point NEP were asked to provide information about their substance-use habits between 2006 and $2014(n=3,680)$ [25]. Based on these responses, it was found that between 2010 and 2014, NPS (mainly synthetic cathinones) gained dominant prevalence among IDUs, with $80 \%$ of the IDUs injecting NPS. Rácz and Csák [26] in their study highlighted the risks of NPS injecting, including the fact that these substances often contain unknown compounds and may induce unpredictable effects and adverse consequences. Tarján et al. [27] also emphasised the risks of increasing hepatitis $\mathrm{C}$ virus (HCV) prevalence, syringe reuse, or daily injection times, especially among NPS injectors. Two papers [28, 29] were dealing with a potential increase in $\mathrm{HCV}$ and HIV prevalence among IDUs, partly as a response to the decreasing harm reduction efforts observed in the country (e.g., closing the largest NEP of Hungary). Tarján et al. [29] described that the prevalence of HCV was doubled between 2011 and 2014 among NPS injectors, whereas Rácz et al. [28] presented new cases of HIV among the clients of two NEPs in Budapest. As it is summarised, mephedrone was only dominant among IDUs in 2010 as first MDPV, later pentedrone became the most commonly injected cathinone derivatives in the following years [16]. These findings are comparable to the reports of the BSZKI [16] as well.

Related to the phenomenon of discarding used needles, two recent studies from the same research group [30, 31] analysed injecting paraphernalia (e.g., discarded syringes) for drug residues of either diverted medication or NPS. 
Their findings suggest that between 2015 and 2016 most common components of the assessed samples ( $n$ of study $1=2,977$ ) were the diverted substitution medication methadone (32\%) and mainly cathinones, such as pentedrone $(18 \%)$, mephedrone $(13 \%)$, alpha-PHP $(8 \%)$, and alpha-PEP (5\%) [31]. Of the 12,762 compound cases ( $n$ of study $2=2,985$ ), $50 \%$ were cathinones [30].

Corazza et al. [32] presented the outcomes of an international collaboration, the Recreational Drugs European Network project, which composed of the qualitative assessments of websites, drug fora, or other online platforms in eight languages from collaborating countries, including Hungary for identifying NPS products. The aim of this study was to explore what types of NPS are being mentioned in the online scene, as well as to overview user reports about the effects of these substances. As an outcome, more than 650 NPS products were identified, out of which 220 were synthetic cannabinoids and 30 cathinone derivatives.

A study by Kapitány-Fövény and Demetrovics [33] assessed the utility of Google Trends in providing relevant information about the web-interest toward mephedrone. This study confirmed the fact that mephedrone reached its popularity when it was still legal. After its legislation, web-interest toward this NPS significantly dropped.

Institóris et al. [34] examined the prevalence of psychoactive substance use (including NPS consumption) among Hungarian Driving Under the Influence of Drugs drivers in 2014 and $2015(N=1,252)$. Positive tests for cathinones (pentedrone and alpha-PVP) occurred in $21 \%-28 \%$, whereas for synthetic cannabinoids in $15 \%-19 \%$ of all cases.

Finally, Kassai et al. [35] - in the framework of a media monitoring study with qualitative content analysis - pointed out that NPS use is rather portrayed from an externalised point of view in the media, emphasising that NPS use is mainly due to low socioeconomic background and mostly a problem of the disadvantaged rural communities and a minority population in general.

\section{Studies on the subjective and somatic effects}

In the past 10 years, both quantitative and qualitative studies assessed the effects of synthetic cathinones and cannabinoids. Considering quantitative measures, Kapitány-Fövény et al. [4] identified six factors of mephedrone-induced subjective effects: (a) positive emotions, (b) sensibility, (c) adverse somatic effects, (d) adverse psychological effects, (e) stimulant effects, and (f) psychedelic effects. Based on their results, users $(n=145)$ mainly prefer psychostimulant and entactogen properties of this NPS. Effects of mephedrone are similar to the effects of MDMA; therefore, synthetic cathninones might function as alternates of formerly banned psychostimulants. Furthermore, those users who inject mephedrone show higher dosages and frequencies of use, higher rates of opiate use, and greater risks of experiencing severe psychiatric symptoms [36]. Similarities between mephedrone and MDMA or cocaine e.g., increased alertness, sexual desire, energy, entactogen effects, and euphoria - were found by Rácz et al. [7] as well.

Among opiate-dependent patients $(n=198)$, most frequent reasons for NPS use were curiosity, the replacement of other drugs and easy availability [37]. Lifetime amphetamine use $(\mathrm{OR}=4.64,95 \%$ CI $[2.16,9.96])$ and more severe psychiatric symptoms $(\mathrm{OR}=1.89,95 \%$ CI [1.18, 3.04]) might increase the odds of synthetic cathinone use among opiate-dependent patients.

Regarding qualitative measures, Kassai et al. [38] analysed the results of semi-structured interviews conducted with synthetic cannabinoid users $(n=6)$ using the method of interpretative phenomenological analysis. Based on the analysis, users perceived synthetic cannabinoids as unpredictable substances, with a significant negative impact on their inter- and intrapersonal life. The high addictive potential of synthetic cannabinoids was also described in the users' responses. Paranoid perceptions were marked consequences of synthetic cannabinoid consumption [39]. Users also stated that synthetic cannabinoids started to take control over their lives. Pintér et al. [40] additionally described that synthetic cannabinoids might transform the identity of users in a very similar way to what a trauma can induce; thus, the use of these NPSs can be interpreted as a form of trauma. Kapitány-Fövény et al. [41] compared the subjective experiences regarding synthetic and natural cannabis consumption as a result of their qualitative research $(n=10)$ and found that synthetic cannabinoids might dominantly provoke adverse and unwanted effects and even somatic withdrawal symptoms (e.g., tremors and sweating). The effect duration of synthetic cannabinoids was shorter than that of cannabis. Main reason for the use of this NPS was low price and easy availability, including home production.

\section{Studies on toxicity and adverse consequences}

Considering synthetic cathinones, MDPV toxicity was described by various papers [42-44], mainly in the form of case studies. Fullajtár and Ferencz [42] were the first in Hungary to describe a case of MDPV-induced psychosis (case of a 34-year-old man). The observed psychotic state was characterised by paranoid ideas and dereistic thinking. As the patient denied the use of other types of drugs as well as no other drug was detectable in urine sample, the psychosis was indeed most likely induced by the consumption of MDPV. Andrássy et al. [43] identified a significant increase in MDPV-related treatment occasions between 2010 and 2012, with 40 recorded cases related to MDPV use. These 40 patients were registered on 87 occasions and most importantly all these cases showed psychotic symptoms. Farkas et al. [44] emphasised the relevance of establishing a clear therapeutic guideline for the treatment of patients suffering from severe MDPV (or other NPS)induced psychiatric symptoms by presenting five different cases of MDPV users.

Consumption of another synthetic cathinone, methylone, was linked to a fatal case of a 16-year-old boy [45]. Gas chromatography/mass spectrometry was used to prove methylone intake $(272 \mathrm{ng} / \mathrm{ml}$ in blood and $387 \mathrm{ng} / \mathrm{g}$ in the liver). As a consequence of methylone use, striated heart muscle damage was observed. Steatosis of the heart muscle, congenital heart disease, and bronchial asthma were listed as potential facilitators of the drug-induced death, with relatively low levels of methylone observed. Szily and Bitter [46] 
outlined the risks of the use of either synthetic cathinones or cannabinoids and highlighted the importance of these NPSs in everyday psychiatric/clinical practice.

With regard to the toxicity of synthetic cannabinoids, Andrássy and Asztalos [47] described both the psychiatric and organic adverse health effects of synthetic cannabinoids, including intense hallucinations, acute renal failure, and developmental pathology of the embryo in the first 2 weeks of childbearing. Cohen et al. [48] compared the effects of synthetic cannabinoids and natural cannabis on cognitive executive functions and found that synthetic cannabinoid users $(n=38)$ performed significantly worse than recreational cannabis users $(n=43)$ or healthy controls ( $n=41)$ on various cognitive tests (e.g., $n$-back test, Stroop word-colour task, and long-term memory task).

Hau et al. [49] presented the case of a 17-year-old drug user with altered mental state, psychiatric symptoms, and autonomic dysfunction caused by N-methyl-D-aspartate (NMDA) encephalitis. Authors described that the repeated intake of synthetic cannabinoids might lead to triggering NMDA encephalitis "via the altered activation of the immune system and molecular mimicry mechanism".

Another less frequently mentioned characteristic of synthetic cannabinoids was introduced by Haskó et al. [50], stating that JWH-133 can decrease the transendothelial migration rate of melanoma cells by activating the CB2 receptors.

\section{DISCUSSION}

Based on our literature review, first synthetic cathinones, then synthetic cannabinoids gained a significant place in the national drug scene. Legislation of these NPSs has led to a decrease in the interest toward them, yet novel substances arose shortly later, replacing formerly banned cathinones and cannabinoids. The overviewed findings suggest that the use of cathinone derivatives - such as MDPV, mephedrone, pentedrone, or methylone - holds severe risks, including psychotic states and fatal overdoses. Synthetic cannabinoids - as compared to natural cannabis - may also induce psychotic symptoms or even facilitate NMDA encephalitis.

As a Hungarian and mainly Central-European specificity, drug change became a marked characteristic among clients of NEPs as well as opiate-dependent patients, resulting in elevated frequencies of cathinone-injecting. The country's decreasing harm reduction efforts might further increase the risk of such behavioural patterns. Users of either synthetic cathinones or cannabinoids experience several adverse effects and still prefer to maintain the consumption. This ambivalence can be explained by practical or economical aspects: low price and easy availability became more important factors than psychopharmacological properties. In this new era of NPSs, users show a rather impulsive pattern of substance use, without considering potential risks of unknown compounds.

Nevertheless, Hungarian prevalence rates - for instance, in the adolescent population - of synthetic cannabinoid and cathinone use are not higher than the European average [3]. Even so, we need to emphasise that the consumption of these NPSs is still a contemporary public health threat, and the effective treatment of NPS users is still a challenge for healthcare practitioners.

\section{CONCLUSIONS}

Our literature review provided a brief overview on the past decade, focussing on the national findings regarding the use of the most common NPSs. At present, there is available information on epidemiology, health risks, and subjective experience related to both cathinone derivatives and synthetic cannabinoids; the cliché stating "we do not know the dangers of these substances" is no longer relevant. We have a strong body of research and empirical evidences to start developing more effective prevention and intervention programs as well as establishing specific therapeutic guidelines for the treatment of NPS users.

Authors' contribution: All persons who met authorship criteria are listed as authors, and all authors certify that they have participated sufficiently in the work.

Conflict of Interest: The authors declare no conflict of interest.

\section{REFERENCES}

1. EMCDDA. New psychoactive substances in Europe. An update from the EU Early Warning System. Lisbon: EMCDDA; 2015 Mar [cited 2017 Sept 15]. Available from: http://www.emcdda. europa.eu/publications/rapid-communications/2015/new-psycho active-substances_en

2. Bretteville-Jensen AL, Tuv SS, Bilgrei OR, Fjeld B, Bachs L. Synthetic cannabinoids and cathinones: prevalence and markets. Forensic Sci Rev. 2013;25(1-2):7-26.

3. ESPAD Group. ESPAD Report 2015 - Results from the European School Survey Project on Alcohol and Other Drugs. Luxembourg: Publications Office of the European Union; 2016.

4. Kapitány-Fövény M, Kertész M, Winstock A, et al. Substitutional potential of mephedrone: an analysis of the subjective effects. Hun Psychopharmacol. 2013;28(4):308-16.

5. EMCDDA. Europol-EMCDDA Joint report on a new psychoactive substance: 4-methylmethcathinone (mephedrone). Lisbon: EMCDDA; 2010 Mar [cited 2017 Sept 15]. Available from: http://www.emcdda.europa.eu/html.cfm/index132196EN. html

6. EMCDDA/ECDC. HIV in injecting drug users in the EU/ EEA, following a reported increase of cases in Greece and Romania. Lisbon: EMCDDA/ECDC, 2012 Jan [cited 2017 Sept 15]. Available from: http://www.emcdda.europa. eu/publications/joint-publications/hiv-in-injecting-drug-users2011_en

7. Rácz J, Csák R, Faragó R, Vadász V. A drogváltás jelensége injekciós droghasználókkal készült interjúkban 
[The phenomenon of drug change in the interviews with injecting drug users]. Psychiatr Hung. 2012;27(1):29-47.

8. Van Hout MC, Bingham T. "A costly turn on": patterns of use and perceived consequences of mephedrone based head shop products amongst Irish injectors. Int $\mathrm{J}$ Drug Policy. 2012;23(3):188-97.

9. Csák R, Demetrovics Z, Rácz J. Transition to injecting 3, 4-methylene-dioxy-pyrovalerone (MDPV) among needle exchange program participants in Hungary. J Psychopharmacol. 2013;27(6):559-63.

10. Árok Z, Csesztregi T, Sija É, et al. Changes in illicit, licit and stimulant designer drug use patterns in South-East Hungary between 2008 and 2015. Leg Med (Tokyo). 2017;28:37-44.

11. Institóris L, Árok Z, Seprenyi K, et al. Frequency and structure of stimulant designer drug consumption among suspected drug users in Budapest and South-East Hungary in 2012-2013. Forensic Sci Int. 2015;248:181-6.

12. Tóth $A R$, Hideg Z, Institóris L. Egy régi-új kábítószer - a mefedron [An old-new illicit drug - mephedrone]. Orv Hetil. 2011;152(30):1192-6.

13. Ujváry I. Növényi tápsó vagy szippantható kokainpótló? - a mefedron tündöklése és bukása [Plant nutrition or snortable substitute of cocaine? - the rise and fall of mephedrone]. Élet Tud. 2010;65(42):1318-21.

14. Ujváry I. Szintetikus kannabinoidok a szabadpiacon fü, füszer, füstölö [Synthetic cannabinoids on the free market - grass, herb, incense]. Élet Tud. 2011;64(32):1002-4.

15. Ujváry I. Új és aggasztó fejlemények az élvezeti célra használt szintetikus pszichoaktív szerek piacán. Második rész [New and alarming proceedings in the market of recreational synthetic psychoactive substances. Part II]. MKL, 2013;68(4):112-5.

16. 2010-2017 National Report to the EMCDDA by the Reitox National Focal Point "Hungary" New developments, trends and in-depth information on selected issues. Available from: http://drogfokuszpont.hu/eves-jelentesek/

17. Németh Á, Költő A (eds.). Serdülőkorú fiatalok egészsége és életmódja. HBSC Nemzeti jelentés, 2010 [Health Behaviour in School-Aged Children (HBSC): AWHO-Collaborative Cross-National Study National Report 2010]. Budapest: Országos Gyermekegészségügyi Intézet; 2011.

18. Elekes Zs. ESPAD 2011 ötödik hullámának magyarországi adatfelvétele [ESPAD 2011- Fifth wave of the European School Survey Project on Alcohol and other Drugs]. Project Report; 2012. Available from: http://real.mtak.hu/12613/1/ 81353_ZJ1.pdf

19. Németh Á, Költő A (eds.). Egészség és egészségmagatartás iskoláskorban [Health Behaviour in School-aged Children (HBSC): A WHO-collaborative Cross-National Study National Report 2014]. Budapest: Nemzeti Egészségfejlesztési Intézet; 2014. Available from: http://www.egeszseg.hu/szakmai_ oldalak/assets/cikkek/16-05/egeszseg-es-egeszsgegmagatartasiskolaskorban-2014.pdf

20. Elekes Zs. ESPAD jelentés 2015 - Rövid összefoglaló a főbb eredményekről [ESPAD report 2015- Brief summary of the main results]. Nemzeti Drog Fókuszpont Hírlevél; 2016 Sept. Available from: http://drogfokuszpont.hu/wp-content/uploads/ NFP_hirlevel_2016_szeptember.pdf

21. Paksi B, Magi A, Felvinczi K, Demetrovics Zs. The prevalence of new psychoactive substances in Hungary - based on a general population survey dealing with addiction related problems (OLAAP 2015). Paper presented at IV. International Conference on Novel Psychoactive Substances (NPS), Budapest, Hungary; 2016 May 30-31.

22. Józan Babák Klub. A Józan Babák Klub 2012. évi beszámolója [2012 annual report of the Sober Babies Club] [cited 2017 Sept 20]. Available from: http://jozanbabakterhesgondozas.blogspot.hu/p/beszamolok.html

23. Csák R, Gyékiss R, Márványkövi $F$, Vadász $V$, Rácz J. Magyarországi intravénás mefedronhasználat a tücsere szolgáltatók tapasztalatai alapján [Injecting mephedrone use in Hungary based on then experiences of needle exchange programs]. Addiktológia [Addictologia Hungarica] 2010; 9(4):281-8.

24. Péterfi A, Tarján A, Horváth GC, Csesztregi T, Nyírády A. Changes in patterns of injecting drug use in Hungary: a shift to synthetic cathinones. Drug Test Anal. 2014;6(7-8):825-31.

25. Rácz J, Csák R, Tóth KT, Tóth E, Rozmán K, Gyarmathy VA. Veni, vidi, vici: the appearance and dominance of new psychoactive substances among new participants at the largest needle exchange program in Hungary between 2006 and 2014. Drug Alcohol Depend. 2016;158:154-8.

26. Rácz J, Csák R. Új pszichoaktív anyagok megjelenése egy Budapest tücsereprogram kliensei körében [Emergence of novel psychoactive substances among clients of a needle exchange program in Budapest]. Orv Hetil. 2014;155(35): 1383-94.

27. Tarján A, Dudás M, Gyarmathy VA, Rusvai E, Tresó B, Csohán Á. Emerging risks due to new injecting patterns in Hungary during austerity times. Subst Use Misuse. 2015;50(7):848-58.

28. Rácz J, Gyarmathy VA, Csák R. New cases of HIV among people who inject drugs in Hungary: false alarm or early warning? Int J Drug Policy. 2016;27:13-6.

29. Tarján A, Dudás M, Wiessing L, et al. HCV prevalence and risk behaviours among injectors of new psychoactive substances in a risk environment in Hungary - an expanding public health burden. Int J Drug Policy. 2017;41:1-7.

30. Péterfi A, Csorba J, Figeczki T, et al. Drug residues in syringes and other injecting paraphernalia in Hungary. Drug Test Anal. 2018;10(2):357-364.

31. Gyarmathy VA, Péterfi A, Figeczki T, et al. Diverted medications and new psychoactive substances - a chemical network analysis of discarded injecting paraphernalia in Hungary. Int J Drug Policy. 2017;46:61-5.

32. Corazza O, Assi S, Simonato P, et al. Promoting innovation and excellence to face the rapid diffusion of novel psychoactive substances in the EU: the outcomes of the ReDNet project. Hum Psychopharmacol. 2013;28(4):317-23.

33. Kapitány-Fövény M, Demetrovics Z. Utility of Web search query data in testing theoretical assumptions about mephedrone. Hum Psychopharmacol. 2017;32(3).

34. Institóris L, Hidvégi E, Dobos A, et al. The role of illicit, licit, and designer drugs in the traffic in Hungary. Forensic Sci Int. 2017;275:234-41.

35. Kassai S, Rácz J, Nagy A, et al. "Someone Else's Problem": new psychoactive substances in the online Hungarian media. J Psychoactive Drugs. 2017;49(1):47-51.

36. Kapitány-Fövény M, Mervó $B$, Kertész M, et al. Is there any difference in patterns of use and psychiatric symptom status between injectors and non-injectors of mephedrone? Hun Psychopharmacol. 2015;30(4):233-43. 
37. Kapitány-Fövény M, Farkas J, Pataki PA, et al. Novel psychoactive substance use among treatment-seeking opiate users: the role of life events and psychiatric symptoms. Hum Psychopharmacol. 2017;32(3).

38. Kassai S, Pintér JN, Rácz J, et al. Assessing the experience of using synthetic cannabinoids by means of interpretative phenomenological analysis. Harm Reduct J. 2017;14:9.

39. Kassai S, Pintér NJ, Rácz J. A szintetikus kannabinoid termék használat élménye: interpretatív fenomenológiai analízisen alapuló kutatás [Investigating the experience of using synthetic cannabinoid products - an interpretative phenomenological analysis]. Mentálhig Pszichoszomat. 2016;17(4):297-322.

40. Pintér JN, Kassai S, Rácz J. Szintetikus kannabinoid terméket használók indentitásszerveződésének vizsgálata interpretatív fenomenológiai analízissel [Assessing identity formation of synthetic cannabinoid products' users - an interpretative phenomenological analysis]. Psychiatr Hung. 2016;31(4): 313-26.

41. Kapitány-Fövény M, Farkas J, Csorba J, Szabó T, Demetrovics Z. Különbségek a szintetikus kannabinoidok és a kannabisz szubjektív hatásaiban, a használati mintázatban és a használat okaiban [Differences in subjective effects, consumption patterns and reasons of use between synthetic cannabinoids and cannabis]. Addiktológia [Addictologia Hungarica]. 2013;12:25.

42. Fullajtár M, Ferencz C. Dizájner drog indukálta pszichózis [Designer drug induced psychosis]. Neuropsychopharmacol Hung. 2012;14(2):137-40.

43. Andrássy G, Asztalos Z, Égerházi A, Frecska E. Tapasztalataink MDVP használók körében: prospektív-retrospektív vizsgálat
[Observations of MDPV users: a prospective-retrospective study]. Psychiatr Hung. 2013;28(2):189-94.

44. Farkas K, Sirály E, Szily E, Csukly G, Réthelyi J. A 3, 4-methylenedioxypyrovaleron (MDPV) használatával kapcsolatos klinikai tapasztalatok öt hospitalizált páciens esete kapcsán [Clinical characteristics of 5 hospitalised 3, 4-methylenedioxypyrovalerone (MDPV) users]. Psychiatr Hung. 2013;28(4):431-9.

45. Kovács K, Tóth AR, Kereszty EM. Új dizájner drog: metilonfogyasztással összefüggő haláleset [A new designer drug: methylone related death]. Orv Hetil. 2012;153(7): 271-6.

46. Szily E, Bitter I. Designer drugs in psychiatric practice a review of the literature and the recent situation in Hungary. Neuropsychopharmacol Hung. 2013;15(4):223-31.

47. Andrássy G, Asztalos Z. Új világ, új kannabisz - osztályos tapasztalatok szintetikus kannabinoidokkal [Novel world, novel cannabinoid - experiences with inpatient synthetic cannabinoid users]. OTSZ. 2013;20(5):22-5.

48. Cohen K, Kapitány-Fövény M, Mama Y, et al. The effects of synthetic cannabinoids on executive function. Psychopharmacology (Berl). 2017;234(7):1121-34.

49. Hau L, Csabi G, Rozsai B, Stankovics J, Tenyi T, Hollody K. Anti-N-methyl-D-aspartate receptor encephalitis and drug abuse - the probable role of molecular mimicry or the overstimulation of CB receptors in a 17-year-old adolescent - case report. Neuropsychopharmacol Hung. 2016;18(3):162-4.

50. Haskó J, Fazakas Cs, Molnár J, et al. CB2 receptor activation inhibits melanoma cell transmigration through the blood-brain barrier. Int J Mol Sci. 2014;15(5):8063-74. 